\title{
O jogo alusivo na representação autobiográfica de Clarice Lispector em Um sopro de vida
}

\author{
The alusive game in autobiographical representation of \\ Clarice Lispector in Um sopro de vida
}

\author{
Denise Gonzaga dos Santos Brito* \\ Vânia Lúcia Menezes Torga** \\ André Luis Mitidieri Pereira***
}

\begin{abstract}
RESUMO: Este trabalho tem por objetivo investigar na obra literária Um sopro de vida, de Clarice Lispector, de que forma a escritora tensiona a relação entre narrativa ficcional e gênero autobiográfico, bem como o papel da alusão enquanto estratégia de leitura e de escrita no processo de representação autobiográ-fica. Para a construção deste trabalho, utilizamos a teoria da alusão, com base nos estudos realizados por Torga (2001, 2006), que a considera como estratégia mediadora dos movimentos da interdiscursividade, a qual se constitui no espaço da memória. Acreditamos que a tensão entre o gênero autobiográfico e a narrativa ficcional em Um sopro de vida, de Clarice Lispector, se dá através de estratégias linguístico-discursivas. A alusão atua no processo de representação autobiográfica fazendo um resgate do todo significativo, permitindo relacionar as partes do mosaico de sentidos que é a obra literária.
\end{abstract}

\begin{abstract}
This work aims to investigate, in Um sopro de vida, romance written by Clarice Lispector, how the author purpose the tension between fictional and autobiographical genre, as well the role of allusion, while strategy of reading and writing, in the process of autobiographical representation. For the construction of this work, we used the theory of reference, based on studies by Torga (2001; 2006), which considers the allusion as the strategy that mediates the movement of interdiscursivity, which constitutes itself in the memory space. Provisionally, we believe that the tension between the autobiographical genre and fictional narrative, in Um sopro de vida, by clariceLispector, occurs through linguistic and discursive strategies. The allusion operates in the process of autobiographical representation making a signifycant recovery of the whole, allowing to relate the parts of the mosaic of meanings that is the literary work.
\end{abstract}

\footnotetext{
* Mestra em Letras: Linguagens e Representações pela Universidade Estadual de Santa Cruz (UESC). dnisegonzaga@yahoo.com.br

** Doutora em Linguística pela Universidade Federal de Minas Gerais (UFMG). vltorga@uol.com.br *** Pós-doutor em Estudos Literários pela Universidade Federal do Rio Grande do Sul (UFRGS). mitidierister@gmail.com
} 


\begin{tabular}{lrlr}
\hline PALAVRAS-CHAVE: Alusão. Memória. & KEYWORDS: & Allusion. & Memory. \\
$\begin{array}{l}\text { Autobiografia. } \\
\text { autobiográfica. }\end{array}$ & Representação & $\begin{array}{l}\text { Autobiography. } \\
\text { representation. }\end{array}$ & Autobiographical \\
\hline
\end{tabular}

\section{Introdução}

A escrita autobiográfica na literatura faz-nos pensar nos limites da relação entre a biografia e a obra do escritor. Em tal escrita, cada uma dessas partes possui existência própria. Em alguns textos, contudo, é quase impossível estabelecer uma distinção clara e objetiva entre o que, de fato, faz parte da vida do escritor e o que é apenas ficcional. Isso porque a relação estabelecida nesse tipo de escrita não é unilateral, o que nos leva a crer que a ficção autobiográfica só se torna possível e se concretiza no movimento dialético entre as partes, por meio do qual a vida e a obra dialogam para formar o todo.

Pensando nesse limite tênue entre literatura e autobiografia, propomos como objetivo deste artigo refletir, como na obra literária Um sopro de vida, de Clarice Lispector, a escritora tensiona a relação entre narrativa ficcional e gênero autobiográfico, bem como o papel da alusão, enquanto estratégia de leitura e de escrita no processo de representação autobiográfica.

Acreditamos que a tensão entre o gênero autobiográfico e a narrativa ficcional em Um sopro de vida se dá através de estratégias linguístico-discursivas, mais precisamente, a memória, a metáfora e a metonímia, categorias constituintes do jogo alusivo que possibilitam, na obra literária em análise, um processo de simbiose entre o autobiográfico e o ficcional que remetem ao dentro e ao fora. Ao se utilizar delas, a autora busca elementos do fora inserindo-os no dentro, para, ficcionalmente, retroprojetá-los no fora, num incessante movimento dialético em que as partes não apenas se complementam, formando um todo fragmentário. A alusão atua no processo de representação autobiográfica "costurando" as partes de um certo todo significativo, permitindo relacionar as partes do mosaico de sentidos que é a obra literária. 
Num primeiro momento, apresentamos os conceitos teóricos que sustentam nosso texto, a saber: alusão, metáfora, metonímia, memória e representação autobiográfica, com o intuito de já convidar o leitor a repensar esses conceitos com base na proposta teórica de Vânia Torga (2001; 2006; 2007), Philippe Lejeune (2008) e Mikhail Bakthin (2010), suporte teórico de nossas pesquisas.

Num segundo momento, procuramos aprofundar o conceito de memória também como categoria constituidora da alusão. Assim, conseguimos entender e demonstrar como, pelo jogo alusivo, as memórias de Clarice Lispector, da personagem de Um sopro de vida, Ângela Pralini, e do autor-narrador-personagem plasmam-se para formar uma memória representativa da autora-criadora.

Num terceiro momento, trabalhamos a representação autobiográfica, com enfoque nas representações do eu e do outro no espaço literário, a fim de explorar um pouco mais o conceito de in(acabamento) dos sujeitos e sua aplicação no romance autobiográfico.

Por fim, são tecidas as considerações finais, mas, desde já, esclarecemos que, neste trabalho, não nos propomos a estreitar, mas a alargar, sob a perspectiva dos estudos linguísticos, as fronteiras do debate em torno da autobiografia na literatura, contribuindo teórico-metodologicamente com a alusão como provocadora do movimento de sentidos, da narrativa literária ao possibilitar novas leituras nos gêneros discursivos, especificamente na ficção literária.

\section{Pressupostos teóricos}

A concepção tradicional da estilística concebe a alusão como figura de linguagem que permite ao autor e ao leitor, através de seu conhecimento enciclopédico, fazer referências a outros textos. Jacqueline Authier-Revuz (2007, p. 11) entende que a alusão "põe em cena a enunciação e suas heterogeneidades, a discursividade, o sentido". Segundo a autora, existe "um dizer que toma de 
empréstimo, de forma não explícita, palavras 'do exterior'”. Em Le Grand Robert, Authier-Revuz concorda em dizer que ela é o "modo de despertar a idéia de uma pessoa ou de uma coisa sem a ela fazer expressamente menção" (AUTHIER-REVUZ, 2007, p. 11).

Com base nessa definição, pode-se entender, de acordo com a autora, que a alusão conservaria em si mesma um pouco do sentido original ou "verdadeiro" do texto, de modo que, como um jogo, o enunciador seria capaz de brincar - ludus -, jogando com a possibilidade de dizer uma coisa através de outra. A alusão seria, portanto, um empréstimo que promove em sua linearidade um retorno à origem.

Ainda de acordo com Authier-Revuz, a alusão pertence à modalidade autonímica, uma configuração enunciativa complexa que "corresponde ao desdobramento - metaenunciativo - de um dizer que, em determinado ponto, faz, ao mesmo tempo, uso das palavras para falar de 'coisas', e um retorno, em menção, sobre essas palavras tomadas como objetos"' (AUTHIER-REVUZ, 2007, p. 12). Para a autora, a alusão só acontece se o leitor conseguir reconhecer a semelhança com o jádito ou com sua origem. Caso contrário, será "tranquilamente ignorada sob a igualdade aparente de uma linearidade sem ruptura" (AUTHIER-REVUZ, 2007, p. 24).

Não compartilhamos da ideia de que a alusão só se concretiza, de fato, quando há um retorno à origem, até porque entendemos que ela é provocadora dos possíveis sentidos, e não apenas dos sentidos possíveis. Assim sendo, esses sentidos não devem estar milimetricamente reduzidos ao seu locus de partida, uma vez que eles podem ser produzidos a partir de outras origens, de outros discursos, de outras vozes.

É importante observar, para fins de esclarecimento, que a nossa pesquisa trata a alusão sob a perspectiva da linguística, e não da literatura, embora nos valhamos desta para legitimar aquela. Assim sendo, o que nos interessa, particularmente, não é estudála como fato literário, mas na condição de estratégia potencial do interdiscurso. Nós a entendemos como uma “ação de linguagem, e porque a linguagem é, para nós, ação - 
ela indicia que há o movimento de deslocamento do autor/leitor na busca da construção interativa de sentido nas ações do 'um' e do 'outro'" (TORGA, 2006, p. 22).

Torga, com apoio em Bakthin, aponta para a respondibilidade do autor e do leitor, e evidencia os papéis desempenhados por estes como partícipes da constituição dialética de si e do outro.

Sendo assim, se há um movimento de produção por parte do autor, ele aciona estratégias que agem na constituição de seu leitor, que por sua vez sai da condição de mero ouvinte ou leitor para a posição e construção, também, de um 'outro' no processo de compreensão, interpretação do ouvido ou lido. Aquele que se nomeia ou se constitui 'eu', na relação interativa, constitui discursivamente o 'outro' que, por sua vez, assume, na interlocução, a posição de 'eu' na construção social de um 'outro' ou 'outros' (TORGA, 2007, p. 22).

O conceito de alusão, portanto, mantém uma estreita relação com outro conceito, o de extralocalização, proposto por Bakhtin (2010), em que a excedência de visão se refere ao posicionamento do eu em relação ao outro. A posição extralocalizada permite que o eu construa certa visão mais ou menos totalizante do outro, que não enxerga em si mesmo todas as suas características e peculiaridades, necessitando, dessa forma, do acabamento externo.

O processo de produção de sentido com a alusão se insere exatamente neste contexto, uma vez que, segundo Torga (2006, p. 31), ao construir um texto, o eu, interlocutor, inventa "a si como uma certa construção de linguagem, inventando, também, o outro, o interlocutor, como uma construção de linguagem com a qual se viabiliza a interação". O esquema abaixo, por nós idealizado, visa compreender o movimento dialético pela alusão, que corrobora a recuperação dos sentidos do texto literário. 


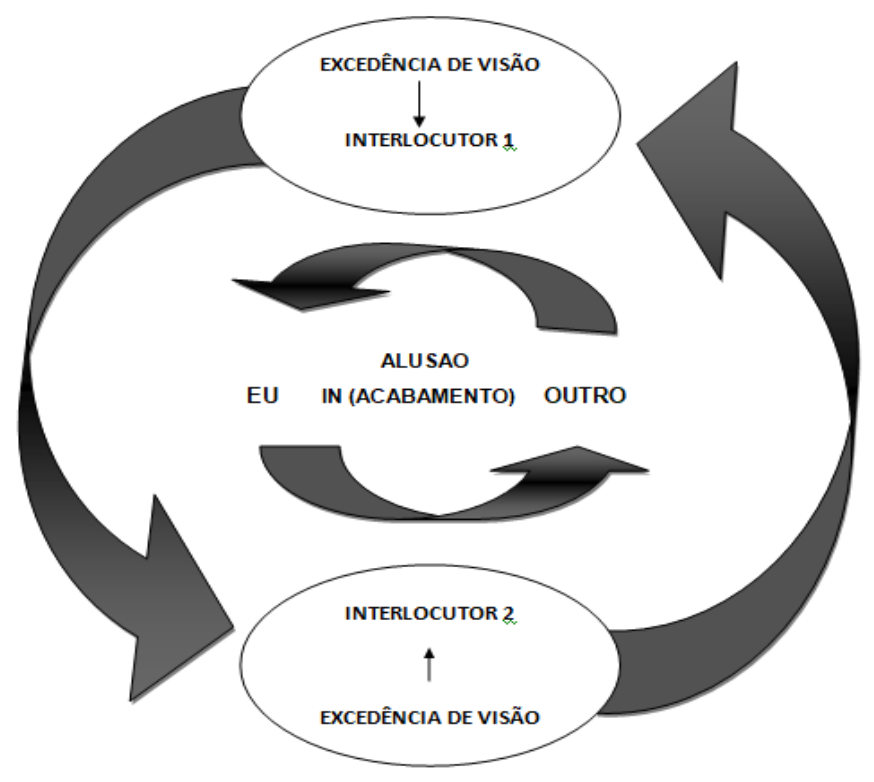

A partir desse esquema, pode-se depreender que a elaboração de um texto e o consequente desvelamento dos seus sentidos exige dos partícipes dessa relação um movimento de busca do um em direção ao outro. É a excedência de visão do autor (interlocutor 1) em relação ao leitor (interlocutor 2) que permite ao primeiro tanto constituir-se como estratégia quanto constituir discursivamente seu interlocutor 2, num movimento constante do um ao outro, do outro ao um, dialeticamente.

Por outro lado, o leitor (interlocutor 2) institui discursivamente o eu da enunciação, para, a partir da sua excedência de visão em relação ao interlocutor 1, constituir o outro(s) ou o(s) sentido(s) do texto, que será(ão) apreendido(s) por intermédio da relação de (in)acabamento do um e do outro, mediados pelo jogo alusivo.

A extralocalização, ou excedência da visão, ocorre quando, mediado pelo jogo alusivo, agente de reprodução e/ou transformação dos sentidos, vai-se além dos sentidos que foram "originalmente" projetados no texto. É essa excedência de visão do leitor que vai indiciar o constante inacabamento de si, do outro e do texto.

Assim sendo, como ocorre em toda relação dialética, o leitor empírico, por meio de seu olhar extralocalizado em relação ao autor empírico, constrói o seu autor- 
modelo, que pode prever não apenas um leitor-modelo, mas vários. É justamente por conta dessa excedência de visão, um movimento dialético da parte/do todo e do todo/da parte que podemos falar do (in)acabamento do texto, porque, se para uma proposta de leitor-modelo, o sentido pode ser recuperado, dando o seu acabamento, uma outra proposta de leitor-modelo pode encontrar outros caminhos, outros atalhos e seguir em outra direção, dando um novo acabamento. Dessa maneira, sempre haverá espaços e caminhos apontando para outras direções, evidenciando o inacabamento do texto literário, corpus de nosso artigo.

Na posição do "eu", o autor institui discursivamente o "outro", que, pelo próprio movimento dialético, assume a posição do "eu" na constituição de "outro(s)". A leitura, mediada pela alusão, indicia justamente esse movimento de busca do "um" em direção ao "outro" e vice-versa, fazendo-nos "pensar na impossibilidade da inocência na leitura" (TORGA, 2006, p. 22). Isso, segundo Umberto Eco (2008, p. 37), significa dizer que o "texto é um mecanismo preguiçoso (ou econômico) que vive da valorização de sentido que o destinatário ali introduziu". Todo texto quer ser revelado, "quer deixar ao leitor a iniciativa interpretativa [...] quer que alguém o ajude a funcionar".

De acordo com Eco (2008, p. 35), o texto possui uma incompletude que é inerente à sua elaboração. Toda e qualquer palavra ou expressão inserida nele, enquanto não for atualizada, permanecerá como flatus vocis, um simples sopro da voz, um som proferido. Ao escrever, o autor aciona uma série de estratégias que vão constituir o seu leitor-modelo, aquele que será “capaz de cooperar para a atualização do texto como ele, autor, pensava, e de movimentar-se interpretativamente conforme ele se movimentou gerativamente" (ECO, 2008, p. 39).

Ainda segundo Eco, na condição de sujeito da enunciação, o autor empírico, aquele que escreve o texto, elabora uma hipótese, através de estratégias, de quem é o seu leitor-modelo. Tal elaboração resulta em uma configuração do próprio autor, agora 
como sujeito do enunciado, tornando-o, também, uma estratégia textual, ou autormodelo. Dessa forma, se, ao escrever, o autor empírico prevê o seu leitor-modelo, o leitor empírico também vai prever um autor-modelo.

A realização do leitor-modelo só é possível, para Eco, se o leitor empírico realizar o que ele chama de deveres filológicos, que seria "o dever de recuperar, com a máxima aproximação possível, os códigos do emitente" (ECO, 2008, p. 47). Ou seja, para ser o leitor-modelo de um autor empírico, o sujeito precisa resgatar todas ou, pelo menos, o maior número de hipóteses, de estratégias por este elaboradas que correspondam, necessariamente, ao projeto de leitura do autor empírico. No entanto, se este pressupõe e até mesmo institui o seu leitor-modelo, ele não limita a atuação do leitor sobre a atividade interpretativa, até porque

\begin{abstract}
A hipótese formulada pelo leitor empírico acerca do próprio Autormodelo parece mais garantida do que aquela que o autor empírico formula acerca do próprio Autor-modelo. Com efeito, o segundo deve postular algo que atualmente ainda não existe e realizá-lo como série de operações textuais; o primeiro, ao invés, deduz uma imagem-tipo de algo que se verificou anteriormente como ato de enunciação e está textualmente presente como enunciado (ECO, 2008, p. 46).
\end{abstract}

Segundo Eco, gerar um texto é executar todos os movimentos previstos pelas estratégias textuais do autor empírico, de modo que se possa chegar às conclusões por ele pretendidas. No entanto, ao movimentar-se no texto, o leitor empírico, que, nesse momento, age de forma responsiva, pode tanto seguir as regras do jogo e se movimentar como previsto, quanto elaborar novas hipóteses, novos caminhos, novos sentidos para o texto.

Sendo assim, se há um movimento de produção por parte do autor, ele aciona estratégias que agem na constituição de seu leitor, que por sua vez sai da condição de mero ouvinte ou leitor para a posição e construção, também, de um 'outro' no processo de compreensão, interpretação do ouvido ou lido (TORGA, 2006, p. 22). 
Em sendo assim, seria possível falarmos que existe um "leitor-modelo" de um determinado autor? Se esse "leitor-modelo" é apenas uma hipótese de leitura prevista pelo autor para que o sentido seja atualizado exatamente da forma como ele imaginou, então podemos supor que o leitor-modelo só existe para o autor empírico. Saber quem é esse leitor-modelo só seria possível, portanto, se fizéssemos uma leitura simétrica de sua obra.

O funcionamento do texto, na perspectiva aqui defendida, é possível, mediado pelas estratégias de leitura e de escrita, mais precisamente da alusão, em conjunto com as categorias que a operacionalizam, a metáfora, a memória e a metonímia. Esse preenchimento semântico dos "espaços em branco", dos "interstícios" com a alusão, não é autoritário nem pretende ser homogeneizador; ao contrário, ele permite a confluência de outros discursos, abrindo-se para um constante devir.

Nesse jogo dialético entre autor e leitor, a alusão surge como mediadora e instiga o leitor a ir além das manifestações lineares do texto, percorrendo toda a obra através do movimento fenomenológico-dialético, destramelando as janelas e espiando mais longe (QUEIRÓS, 1996) para, assim, o(s) sentido(s) do texto vir(virem) a ser. Vale lembrar que o movimento de sentido da alusão é o movimento dialético, no qual as partes indiciam o todo, e o todo indicia as partes, num incessante jogo de possibilidades. Assim, podemos entender que

A alusão é esse movimento dialógico centro/margem/centro, todo/parte/todo, fenômeno/essência/fenômeno. O centro alude à passagem que as margens indiciam nas entrelinhas, nas lacunas. Devido a isso, a alusão enquanto produto, na sua imediaticidade, indicia, metodologicamente, o processo de investigação e pesquisa que se situa no plano da mediaticidade (TORGA, 2001, p. 13).

Com base na fenomenologia dialética, de Karel Kosik, podemos entender metodologicamente a alusão - estratégia que é acionada durante as leituras/escritas -, permitindo olhar o texto clariceano com o já-sido no ainda-não em-sendo, em que, 
"num determinado campo de análise, as partes atuam na configuração do todo, mas este, por sua vez, reflui sobre os pontos de partida" (RAMOS, 1974, apud TORGA, 2001, p. 12). Segundo Kosik (1995, p. 16),

O mundo fenomênico, porém, não é algo independente e absoluto; os fenômenos se transformam em mundo fenomênico na relação com a essência. [...]. Captar o fenômeno de determinada coisa significa indagar e descrever como a coisa em si se manifesta naquele fenômeno, e como ao mesmo tempo nele se esconde. Compreender o fenômeno é atingir a essência.

No pensamento fenomenológico-dialético, as partes não são dadas, nem mesmo o todo. A investigação e a pesquisa consistem na estruturação do conceito com a mediação da teoria e do método que se articulam às manifestações fenomênicas, quando certa configuração do todo e da parte, dialeticamente, é produzida.

A alusão, atuando na constituição do sentido do texto, pode resultar tanto numa relação simétrica quanto assimétrica. A leitura, pela alusão, instiga, permite ao leitor delinear os sentidos do texto. A partir desse novo conceito, desse novo lugar, podemos ressignificar a alusão, entendendo-a como mediadora de leitura e escrita "que oferece as pistas articulatórias" (TORGA, 2001, p. 29) capazes de permitir ao leitor relacionar as partes do mosaico de sentidos que é a obra literária. A alusão se torna, portanto, não uma categoria fraca da intertextualidade, mas uma "estratégia mediadora dos movimentos da interdiscursividade" que, "de forma sutil, perturbadora e criadora, produz o movimento de ir, vir e devir"' (TORGA, 2001, 2006).

Investigando as possibilidades de sentidos em Um sopro de vida, de Clarice Lispector, entendemos a alusão como estratégia mediadora, pois, como se sabe, os textos clariceanos são dotados de peculiaridades que tornam a autora um caso ímpar na literatura brasileira. Apesar de não ser a única escritora brasileira que inseriu em seus textos impressões autobiográficas, Clarice soube trabalhar os elementos da vida e da ficção de tal forma que o imbricamento desses elementos forma para o leitor um 
todo fragmentário, no qual, ao mesmo tempo em que se tem a possibilidade de leitura pelo viés do real, tem-se também, como no signo saussuriano, a outra face inseparável dessa leitura, a ficção.

Como a própria Clarice já havia dito, o seu texto é alusivo. Para dizer uma coisa, muitas vezes Clarice dizia outra(s) ou até mesmo nada, porque o silêncio lhe bastava. A desficcionalização dos textos de Clarice Lispector é marcada "pela sua inscrição, como pessoa e escritora, na sua obra, registrando fatos diários, em sequência por vezes com intervalo de poucos minutos, num conjunto autobiográfico, ainda que supostamente involuntário" (GOTLIB, 2009). Esse conjunto aparece para nós, leitores, através das alusões feitas nos textos. Vale lembrar que a alusão é uma estratégia sutil de leitura; ela ajuda a revelar o sentido do texto a partir de pequenos índices, de pequenas citações, que muitas vezes só podem ser percebidas "por intermédio de palavras que ocultam outras - as verdadeiras" (LISPECTOR, 1999s, p. 74). Assim sendo, muitas vezes, o conjunto autobiográfico da escritora "aparece sutilmente pela sugestão de um pormenor"' (GOTLIB, 2009, p. 527).

Clarice não gostava de falar dos fatos de seu passado. De acordo com Benjamin Moser (2009, p. 16), “ela fez o possível, na vida e na escrita para apagá-los. Por outro lado, porém, poucas pessoas se expuseram tão completamente". Era através da literatura que a escritora, aos poucos, se revelava e se reinventava. Para ela, talvez, a literatura fosse uma espécie de mensageira de si para si mesma e para o mundo. Não por acaso, talvez, a personagem Ângela Pralini tenha esse nome. Ângela Pralini é o título da identidade trêmula do narrador, que busca, através de Ângela, uma representação de si mesmo: "Nenhum ato meu sou eu. Ângela será o ato que me representará" (LISPECTOR, 1999s, p. 41). No entanto o narrador tem consciência de que essa representação é limitada, e avisa ao leitor sobre a impossibilidade de uma representação "fiel" à realidade: "nenhum ato me simboliza" (LISPECTOR, 1999s, p. 37). 
O nome Ângela significa "anjo", "mensageiro", e faz alusão à função da personagem na narrativa, que tem, entre outros, o papel de intermediar a relação da escritora com os diversos eus que a habitam e com o mundo. Ângela, como mensageira, tem a função de dizer e expressar aquilo que o narrador não pode ou não quer dizer, por achar inútil. É uma forma também de expurgar os sentimentos do autor:

Amo Ângela, porque ela diz o que não tenho coragem de dizer porque temo a mim mesmo? Ou porque acho inútil falar? Porque o que se fala se perde como hálito que sai da boca quando se fala e se perde aquela porção de hálito para sempre (LISPECTOR, 1999s, p.38).

Essa função de mensageira é percebida nas citações seguintes:

Ei-la falando como se fosse comigo mas fala para o ar e nem sequer para si mesma e só eu aproveito do que ela fala porque ela é de mim para mim (LISPECTOR, 1999s, p. 38).

Recebo mensagens de mim para si mesma (LISPECTOR, 1999s, p. 55).

As mensagens enviadas por intermédio de Ângela partem, assim, do próprio narrador. A utilização de dois pronomes, um de primeira e outro de terceira pessoa, indicia que há uma troca entre dois interlocutores de gêneros distintos e que cabe a Ângela fazer essa intermediação.

\subsection{Alusão e metáfora}

Na literatura, em especial, a metáfora possui uma função muito particular, que é expressar o inexprimível, rompendo a lógica da linguagem ao transcendê-la. Além disso, seu uso serve à hermenêutica, uma vez que possibilita ao leitor a criação de sentidos exofóricos, que, por sua vez, encontram na alusão uma parceira ideal para uma leitura de relações simétricas e/ou assimétricas. Tal leitura é potencializada pela 
ação metafórica da linguagem, visto que a metáfora, por ser original, ambígua, sugere ao leitor uma série de possibilidades interpretativas, permitindo-lhe estabelecer relações surpreendentes.

Diante da metáfora, tem-se sempre um novo produto, nunca igual ao elemento comparado, até porque, se assim fosse, a metáfora perderia todo o seu sentido, já que, em termos de comparação, não existe lógica ao dizer que uma coisa é igual a si mesma. Para muitos estudiosos, a linguagem é, eminentemente, metafórica. Isso porque as palavras nunca são o que realmente designam. A linguagem torna, portanto, fosca a realidade.

Segundo Torga (2007, p. 199), “a metáfora é a possibilidade que a linguagem oferece de se descobrir semelhanças", promovendo desta forma "o movimento da reunião do que está disperso" (TORGA, 2006, p.110). A metáfora, portanto, como categoria constituidora do jogo alusivo, permite ao leitor formar a figura do todo a partir da condensação de uma parte, a qual, por sua vez, se identifica com o todo, o que nos permite afirmar que

A metáfora, pela condensação, atuaria na linha da reprodução da relação todo/parte, a parte se identificaria com o todo. A reprodução não anularia a contradição. Mascararia a divisão e como tal se sujeita à ação da contradição. [...]. Na metáfora, a parte é produzida para ser equivalente ao todo, de forma que a relação todo/parte, ou parte/todo possa ser vista pretensamente na condensação do todo, mas contraditoriamente a parte jamais suprime a diferença entre as partes que concorrem ao mesmo lugar do todo (abriga a heterogeneidade, a diferença) (TORGA, 2007, p. 199).

Sob a perspectiva da alusão, a metáfora ganha uma nova roupagem e significado. Além de participar do processo criativo da linguagem, da inovação linguístico-semântica, a metáfora, pela condensação das partes, possibilita a leitura através da relação parte/todo/parte. Tal leitura não esconde o fenômeno da contradição; ao contrário, a contradição se abre para abrigar a heterogeneidade. Assim 
sendo, a leitura pela metáfora, como categoria constituidora do jogo alusivo, busca estabelecer as relações entre o todo e a parte, construindo a figura do todo a partir das relações entre as partes.

Em Um sopro de vida, percebemos muitas metáforas que corroboram a nossa hipótese de representação autobiográfica de Clarice Lispector em seus textos. Entre elas, destacamos a metáfora do espelho.

Pela ação metonímica, refletindo as partes, o espelho forma a figura de um certo todo, que, por sua vez, alude ao processo de representação autobiográfica no corpus. A personagem Ângela Pralini é considerada pelo narrador um espelho seu. Já Ângela se considera o seu próprio espelho, ou seja, ela já é uma representação de si mesma, que, por sua vez, é uma representação do narrador, o qual é uma representação da própria Clarice Lispector. Com isso, a escritora vai brincando de criar e de representar a si mesma na literatura.

Tive um sonho nítido inexplicável: sonhei que brincava com o meu reflexo. Mas meu reflexo não estava num espelho, mas refletia uma outra pessoa que não eu [...] Ângela é um espelho (LISPECTOR, 1999s, p. 26-27).

Eu sou o meu próprio espelho (LISPECTOR, 1999s, p. 65).

Para Chevalier e Gheerbrant (1995, p. 394), na tradição nipônica, o espelho está relacionado com a revelação da verdade e com a pureza. É também tanto um “símbolo da manifestação que reflete a inteligência criativa" quanto do "intelecto divino que reflete a manifestação, criando-a como tal à sua imagem".

No Japão, o Kagami, ou o espelho, é símbolo da pureza perfeita da alma, de um espírito imaculado, representando, assim, a reflexão de si na consciência (CHEVALIER; GHEERBRANT, 1995). No entanto, além dessa pretensa revelação do real, há ainda a consideração, segundo os estudiosos dos símbolos, de que o espelho provoca uma imagem refratada da realidade, não havendo, dessa forma, uma 
fidelidade ao original. É o que podemos notar na seguinte passagem de Um sopro de vida:

Minha vida é um reflexo deformado assim como se deforma num lago ondulante e instável o reflexo de um rosto. Imprecisão trêmula. Como o que acontece com a água quando se mergulha a mão na água. Sou um palidíssimo reflexo de erudição. Minha receptividade se afina registrando sem parar as concepções de outros, refletindo no meu espelho os matizes sutis das distinções entre as coisas da vida (LISPECTOR, 1999s, p. 47).

O que fica registrado para nós nessa metáfora é justamente essa impossibilidade de a escritora se refletir em seus textos. Se, por um lado, a tradição nipônica supõe que o espelho reflete uma imagem real, o que nos dá a sensação de que é a própria escritora que se confidencia nos seus textos, por outro, não se pode esquecer que essa imagem é, na verdade, refratada e, portanto, não reveladora da verdade, mas de uma verdade própria, particular, que reside em si mesma.

A imagem, portanto, ao ser refletida no espelho, sofre uma transformação. $O$ sujeito contemplado (o narrador) e o espelho (Ângela Pralini) passam a ser parte um do outro, numa relação que os leva a um processo maior de simbiose entre o real e o ficcional. O espelho retrata, dessa forma, a imagem de um outro de si mesmo, o outro possível que habita a nossa consciência quando fantasiamos, quando criamos. Procuramos dar a esse outro de si mesmo a possibilidade de viver aquilo que não podemos, de concretizar os sonhos que não realizamos:

O autor de biografia é aquele outro possível, pelo qual somos mais facilmente possuídos na vida, que está conosco quando nos olhamos no espelho, quando sonhamos com a fama, fazemos planos externos para a vida; é o outro possível, que se infiltrou na nossa consciência e frequentemente dirige os nossos atos, apreciações e visão de nós mesmos ao lado do nosso eu-para-si; é o outro na consciência, com quem a vida pode ser suficientemente móvel (BAKHTIN, 2010, p. 140). 
Através de Ângela Pralini, o outro eu do narrador, que, por sua vez, é o outro eu de Clarice Lispector, a escritora pode, como na contemplação de um espelho, criar uma realidade nova ao duplicar a sua imagem. Essa leitura é possível graças à alusão, responsável - juntamente com a metáfora e a metonímia, categorias constituidoras do jogo alusivo - por permitir que o leitor recupere ou transforme o(s) sentido(s) do texto literário.

\subsection{Alusão e metonímia}

Pensamos a metonímia numa perspectiva mais abrangente do que aquela que a concepção tradicional tem proposto. Da mesma forma que a metáfora, a metonímia atua na operacionalização do jogo alusivo, permitindo ao leitor formar a figura de um certo todo. "Pela metonímia, temos o movimento de deslocamento, em que o todo se desloca, em partes, fragmentos dele" (TORGA, 2007, p. 198). Na metonímia, apesar de as partes serem autônomas, elas mantêm relação com o todo, ganhando nele o seu significado geral. Podemos esclarecer a relação entre a alusão, a metáfora e a metonímia a partir da ilustração que elaboramos abaixo:

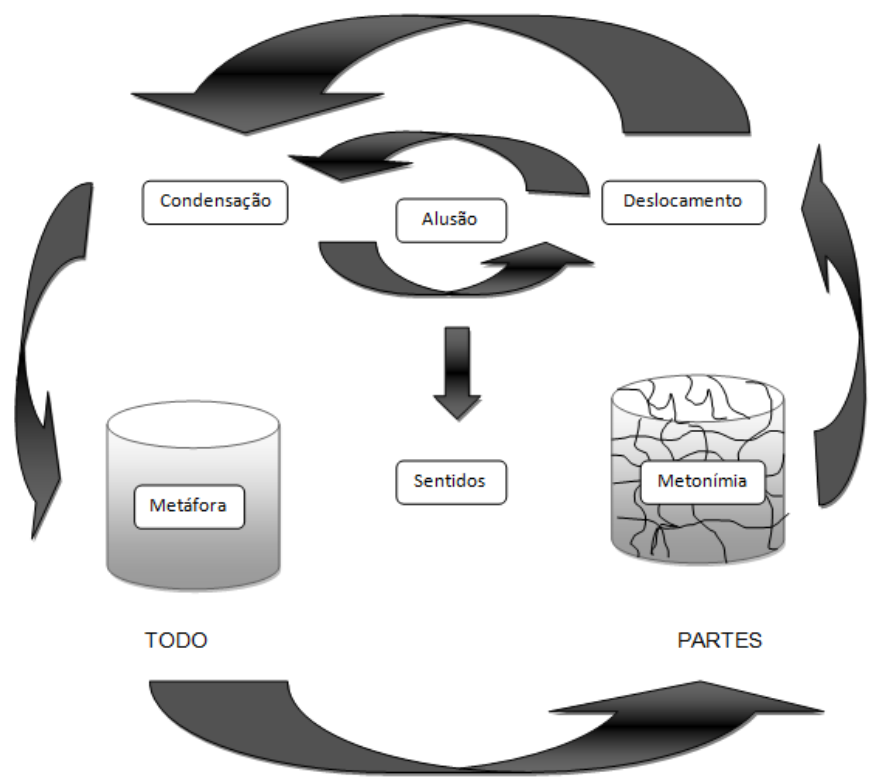


De acordo com Torga (2007), pela condensação, a metáfora atua na linha da reprodução; o todo, pela ação metonímica da linguagem, se fragmenta em partes. A metonímia, por sua vez, pelo movimento de deslocamento, forma um certo todo. Assim sendo, as partes se identificam com esse todo. No entanto, por mascarar a divisão, a metáfora está, pois, sujeita à ação da contradição. Isso porque, sendo o todo formado por partes, essas partes não são o todo, porque, em sendo partes, o todo, pela condensação, semanticamente, vai ganhando novo sentido. Tanto a metáfora quanto a metonímia são consideradas por nós como categorias constituidoras da alusão, estratégia que permite ao leitor recuperar o(s) sentido(s) do texto literário.

O movimento de deslocamento de sentido por ação metonímica das partes faz surgir o movimento de condensação da metáfora e vice-versa, operacionalizando a alusão, para que esta possa, através do movimento que surge da relação todo/parte e parte/todo, indiciar os sentidos do texto. Por isso, podemos dizer que a metáfora pressupõe a metonímia e que a metonímia, por sua vez, pressupõe a metáfora.

O movimento de sentido da alusão pela ação metafórica e metonímica pode ser percebido no corpus desta investigação através da relação que se estabelece entre o autor-narrador-personagem e Ângela Pralini. A criação de Ângela surge da necessidade que o autor-narrador-personagem tem de entender a falta de definição da vida através de um diálogo interior. Ambas as personagens se dividem metonimicamente para formar um certo todo com as metáforas que vão aludir à representação autobiográfica de Clarice Lispector em Um sopro de vida. O deslocamento e a posterior condensação são apresentados ao longo do texto. Selecionamos alguns trechos em que podemos perceber esse movimento do todo/parte/todo:

\section{Deslocamento}

Ângela é muito parecida com o meu contraditório. Ter dentro do mim o contrário do que sou é em essência imprescindível (LISPECTOR, 1999s, p. 46). 
Criar um ser que me contraponha é dentro do silêncio (LISPECTOR, 1999s, p. 29).

Ângela é minha variação? (LISPECTOR, 1999s, p. 51).

Isto afinal é um diálogo ou um duplo diário? (LISPECTOR, 1999s, p. 36).

Ângela é a minha tentativa de ser dois (LISPECTOR, 1999s, p. 36).

Até onde vou eu e em onde já começo a ser Ângela? Somos frutos da mesma árvore? Não - Ângela é tudo o que eu queria ser e não fui. O que é ela? ela é as ondas do mar. Enquanto eu sou floresta espessa e sombria. Eu sou no fundo. Ângela se espalha em estilhaços brilhantes. Ângela é a minha vertigem (LISPECTOR, 1999s, p. 30).

\section{Condensação}

Ângela significa o único ser que ela é: só existe uma Ângela. Nenhum ato meu sou eu. Ângela será o ato que me representará (LISPECTOR, 1999s, p. 41).

Eu e Ângela somos o meu diálogo interior: converso comigo mesmo. Ângela é do meu interior escuro: ela porém vem à luz (LISPECTOR, 1999s, p. 73).

No sonho do real parece que não sou eu que estou vivendo e sim outra pessoa. Essa outra pessoa é Ângela que é meu sonho acordado. Estou falando eu ou está falando Ângela? Não existe realidade em si mesma. O que há é ver a verdade através do sonho. A vida real é apenas simbólica: ela se refere a alguma outra coisa (LISPECTOR, 1999s, p. 83).

Eu, gazela espavorida e borboleta amarela. Eu não passo de uma vírgula na vida. Eu que sou dois pontos. Tu, és a minha exclamação. Eu te respiro-me (LISPECTOR, 1999s, p. 37).

Os fragmentos supracitados revelam o movimento metonímico das partes em direção ao todo. Nas citações relativas ao deslocamento, tem-se uma divisão dos sujeitos da narrativa. Ângela é nesse sentido um contraponto do autor, talvez uma variação sua, mas não ele enquanto si mesmo. Essa perspectiva pode ser comprovada 
a partir da leitura dos fragmentos que se referem ao movimento de condensação, no qual o eu do autor se funde ao eu de Ângela, formando um outro enquanto representação de si. O imbricamento entre o autor e Ângela é marcado principalmente pela construção linguístico-semântica da fala de Ângela, que faz uso dos pronomes proclítico e enclítico na mesma construção verbal para referir-se à primeira e à segunda pessoa do discurso ao mesmo tempo, fundindo-as em uma única pessoa.

O movimento metonímico/metafórico nos conduz à metáfora do fac-símile:

Estou alvoroçado e apreensivo: não é fácil lidar com Ângela, a mulher que inventei porque precisava de um fac-símile de diálogo (LISPECTOR, 1999s, p. 28).

Eu sempre quis achar um dia uma pessoa que vivesse por mim pois a vida é tão repleta de coisas inúteis que só a agüento com astenia muscular in extremis, tenho preguiça moral de viver. Pretendi fazer com que Ângela vivesse em meu lugar - mas também ela só quer o clímax da vida. Será que criei Ângela para ter um diálogo comigo mesmo? Eu inventei Ângela porque preciso me inventar - Ângela é uma espantada (LISPECTOR, 1999s, p. 31).

Eu e Ângela somos o meu diálogo interior: converso comigo mesmo (LISPECTOR, 1999s, p. 73).

Como se sabe, o fac-símile não é o real, mas uma cópia, uma representação desse real. A metáfora do fac-sílime vai, portanto, aludir à representação autobiográfica de Clarice Lispector em Um sopro de vida.

Através das muitas facetas de sua obra - em romances, contos, cartas e textos jornalísticos, na esplêndida prosa - uma personalidade única é dissecada sem descanso e revelada de modo fascinante naquela que é talvez a maior autobiografia espiritual do século XX (MOSER, 2009, p. 16). 
O trabalho com a alusão permite um olhar além, transformador dos sentidos do texto, permitindo-nos trabalhar o corpus a partir de uma nova possibilidade interpretativa, a saber, a de uma representação autobiográfica da escritora Clarice Lispector no texto ficcional. A alusão é a estratégia linguístico-discursiva mediadora do movimento interdiscursivo, que autoriza e permite essa relação entre o real e o ficcional e que, juntamente com a metáfora, a metonímia, a memória e o silêncio, categorias constituidoras do jogo alusivo, reconstrói o todo semântico do produto ficcional, levando o leitor a assumir o seu papel como partícipe da produção/recepção do texto literário.

\subsection{O movimento da memória no jogo alusivo}

A fala de si mesmo pauta-se na memória, havendo nela uma conjunção dos três tempos: passado, presente e futuro. A memória funciona como um signo do vivido e, nessa condição de signo, é constituída pela linguagem, provocando um movimento, que seria o

movimento do já-sido em direção ao que ainda não é em sendo, ou seja, um passado que pelo presente indicia o futuro. [...] Esse movimento [...] caracteriza a dinamicidade do real que embora linear é constituído de fragmentos, rupturas, partes, faltas, silêncios, porque neste real está o sujeito rememorador (TORGA, 2001, p. 57).

Assim, o passado, representado através da memória, “já-não-é”; ele será sempre um "em-sendo" e, no "em-sendo", o "ainda-não", que vai se constituindo e se atualizando no instante-já. Podemos, dessa forma, concordar com Torga (2007, p.1) quando ela diz que

A memória não reproduz absolutamente o que foi, mas refaz o passado, reconstrói o vivido sob o olhar do tempo presente que não é apenas individual, mas social. Exige, pois, um trabalho de transformação, mas, como num palimpsesto, conserva, relativamente, 
as características do todo de que é parte e do qual a memória faz o recorte ao lembrar o que significa.

Nesse esforço em reconstruir os fatos pretéritos, os processos de elaboração e reelaboração do passado, ainda que de forma inconsciente por parte do sujeito rememorador, sofrem interferência direta do presente, e, como o espelho refrata o conteúdo da memória e, com isso, o real, aponta, dessa forma, para uma dupla realidade.

\subsubsection{Memória e autobiografia}

A autobiografia, bem como todos os outros gêneros canônicos do espaço biográfico, ${ }^{1}$ se articulam num jogo duplo, no qual, ao mesmo tempo, aquilo que é histórico é também ficção (Cf. ARFUCH, 2010). Isso porque uma das formas constitutivas do gênero autobiográfico é justamente a oscilação existente entre mímesis e memória, "entre uma lógica representativa dos fatos e o fluxo das lembranças, mesmo reconhecidamente arbitrário e distorcedor" (ARFUCH, 2010, p. 135).

A autobiografia e os gêneros autobiográficos lidam com a memória e com o esquecimento, e é a partir da memória que os elementos pertinentes ao plano éticocognitivo do sujeito rememorador podem ser narrados e identificados no plano estético.

A memória, também categoria constituidora do jogo alusivo, permite à autora empírica, em Um sopro de vida, relacionar os fatos de sua vida aos de suas personagens, criando uma espécie de simbiose entre o real e o ficcional. Cabe aos leitores empíricos

\footnotetext{
${ }^{1}$ Arfuch (2010, p. 22) toma emprestado o termo utilizado por Philippe Lejeune, o qual tentou "aprisionar a 'especificidade' da autobiografia como centro de um sistema de gêneros literários afins". O espaço biográfico de Lejeune buscava abarcar as diversas formas que a autobiografia foi ganhando ao longo dos tempos e funcionava "como um reservatório onde cada espécime fornece um 'exemplo'". No entanto, em Arfuch, esse termo é ampliado e passa a significar um espaço comum de intelecção das narrativas biográficas, que não se limita às formas canônicas, mas se abre para as confluências dos gêneros, para a hibridização, "sem renunciar a uma temporalização, a uma busca de heranças e genealogias, a postular relações de presença e ausência".
} 
encontrar o limite tênue que separa a vida da arte. $\mathrm{O}$ fato é que a memória das personagens, em alguns momentos até mais explicitamente, passa pela memória da escritora. Por isso, faz-se mister entender a relação entre alusão, memória e representação autobiográfica.

\subsubsection{Alusão e memória}

A memória, assim como a metáfora, a metonímia e o silêncio, é uma das categorias da alusão que permite ao leitor preencher os espaços em branco deixados pelo autor-empírico.

O vivido pela imagem enquanto representação remete ao caráter de signo que a memória tem, e como tal, é pela linguagem que ela se constrói, num movimento do já-sido em direção ao que ainda não é em sendo, ou seja, um passado que pelo presente indicia o futuro (TORGA, 2007, p. 57).

Segundo Torga (2007), esse movimento aponta para a dinamicidade do real, o qual, apesar de ser linear, constitui-se de fragmentos, por conta da presença do sujeito rememorador nesse real. Assim sendo, a relação que se estabelece entre o sujeito rememorador e o real é de complementaridade, uma vez que, para lembrar, é preciso esquecer, de modo que a alusão lida não apenas com a memória, com o lembrar, mas também com o seu contrário.

Por entendermos que "A relação do já-dito com um Outro do discurso remetenos à interdiscursividade, à remissão a outros discursos" (TORGA, 2001, p. 68), que pela memória pode ser atualizado no presente, propomos aqui uma leitura pela alusão, resgatando fatos e impressões que permeiam a memória da escritora Clarice Lispector e que são representados ficcionalmente no corpus por meio da memória e das impressões de Ângela Pralini e do autor.

AUTOR. - [...] Quero esquecer que jamais esqueci. Quero esquecer elogios 
e os apupos. Quero me reinaugurar. E para isso tenho que abdicar de toda a minha obra e começar humildemente, sem endeusamento, de um começo em que não haja resquícios de qualquer hábito, cacoetes ou habilidades. $\mathrm{O}$ know-how eu tenho que pôr de lado. Para isso eu me exponho a um novo tipo de ficção, que eu nem sei ainda como manejar. O principal a que eu quero chegar é surpreender-me a mim mesmo com o que escrevo. Ser tomado de assalto: estremecer diante do que nunca foi dito por mim (LISPECTOR, 1999s, p. 71-72).

Esquecer para lembrar, para escrever, para se reinventar. Pela estratégia do esquecimento, o autor busca se livrar do endeusamento que fazem dele e, assim, inaugurar uma nova forma de dizer, de se expressar através da escrita. Esse distanciamento de uma imagem construída em torno do autor alude à relação de Clarice Lispector com os leitores e a crítica, que ao longo de sua produção começaram a endeusá-la. Talvez para tentar se livrar desse peso, Clarice tenha escrito Uma aprendizagem ou O livro dos prazeres. Essa obra literária, diferentemente do livro que a antecedeu, A paixão segundo GH, e de outros sob autoria de Clarice, sugere uma humanização da escritora, o que foi confirmado por ela mesma ao afirmar, durante uma entrevista, que o romance tinha de fato uma leitura mais fácil porque ela havia se humanizado.

Em uma das perguntas que fez a Fernando Sabino, diálogo registrado no livro Entrevistas, Clarice disse que o sucesso quase lhe fazia mal, e o encarava como invasão (LISPECTOR, 2007). A condição de escritora famosa, consagrada, a incomodava em função do peso que tal situação representava e, por isso, se valia da ironia para criticar a midiatização de sua obra. Este, aliás, é outro desabafo feito na voz do autor:

\footnotetext{
AUTOR.- Me coisificam quando me chamam de escritor. Nunca fui e nunca serei. Recuso-me a ter papel de escriba no mundo.

Eu odeio quando me mandam escrever ou quando esperam que eu escreva. Recebi uma vez uma carta anônima que me oferecia espiritualmente um recital de música contanto que eu continuasse a escrever. Resultado: parei completamente. Só quem manda em mim - eu é que sei (LISPECTOR, 1999s, p. 97).
} 
De modo algum queremos aqui defender a ideia de que essas memórias ficcionalizadas no texto são exatamente as mesmas da escritora Clarice Lispector, até porque isso invalidaria todo o nosso trabalho. No entanto, há de se considerar uma aproximação ou uma coincidência mnemônica que perpassa tanto a vida do autor quanto a de Clarice e nos faz pensar numa leitura, possível, voltada para a interpretação autobiográfica em Um sopro de vida.

\subsubsection{A memória em Um sopro de vida}

As memórias dos sujeitos enunciativos de Um sopro de vida, marcadas pelas relações de subjetividade e alteridade, entrelaçam-se, provocando uma plasmação da identidade desses sujeitos. A memória deles, portanto, construída a partir da performance discursiva dos enunciados, é formada no trânsito das narrativas do outro (Cf. BUSATO, 2010).

A relação de Clarice com o mundo, com suas experiências de vida e as lembranças da infância, é recriada, reelaborada na literatura, marcando um dos traços da escritora. É justamente por conta dessa recriação na literatura de alguns eventos que coincidem com os fatos da vida de Clarice que

Não se pode afirmar que a narradora conte aí exatamente o que lhe aconteceu. Afinal, a narradora da história conta o que aconteceu depois que o fato já passou e muitos detalhes ficaram perdidos na memória. Além disso, há sempre interferências criadoras, ainda que mínimas, de quem conta. Nem se pode confiar em tudo o que a narradora-Clarice afirma, já que ela por vezes dissimula, inventa. [...] - o que é real e o que é ficção? - nunca poderemos identificar com certeza (GOTLIB, 2009, p. 65).

No entanto, se, por um lado, não se pode confiar no que Clarice conta de sua vida nos textos, de modo que, como muito bem pontuou Gotlib (2009), nunca poderemos separar com total precisão e certeza o que é real e o que é ficção, por outro, 
pode-se encontrar o motivo que originou tal escrita. Como os limites entre o real e o ficcional são nitidamente borrados, os leitores passam a ser partícipes dessa (re)construção do passado da escritora, executando sua tarefa com base nos pequenos índices e citações presentes no texto.

Entendendo que a rememoração é uma forma de construção do passado no tempo presente, selecionamos alguns trechos em que o autor e Ângela aludem, por intermédio da provocação da memória, a alguns fatos e impressões da vida de Clarice Lispector como a fase em que a escritora trabalhou como cronista para o Jornal do Brasil. Uma das impressões de Clarice sobre as crônicas, por exemplo, é ficcionalizada em Um sopro de vida. Ângela Pralini, assim como Clarice, escrevia crônicas semanais para um jornal. Todavia ambas se sentiam insatisfeitas com essa função:

Ângela escreve crônicas para o jornal. Crônicas semanais, mas não fica satisfeita. Crônica não é literatura, é paraliteratura. Os outros podem achálas de boa qualidade mas ela as considera medíocres. Queria era escrever um romance mas isso é impossível porque não tem fôlego para tanto. Seus contos foram rejeitados pelas editoras, alguns dizendo que eles são muito longe da realidade. Vai tentar escrever um dentro da "realidade" dos outros, mas isso seria se abastardar (LISPECTOR, 1999s, p. 98).

Outra coisa notei: basta eu saber que estou escrevendo para jornal, isto é, para algo aberto facilmente por todo o mundo, e não para um livro, que só é aberto por quem realmente quer, para que, mesmo sem sentir, o modo de escrever se transforme. Não é que me desagrade mudar, pelo contrário. Mas queria que fossem mudanças mais profundas e interiores que então viessem a se refletir no escrever. Mas mudar só porque isto é uma coluna ou uma crônica? Ser mais leve só porque o leitor assim o quer? Divertir? Fazer passar uns minutos de leitura? E outra coisa: nos meus livros quero profundamente a comunicação profunda comigo e com o leitor. Aqui no jornal apenas falo com o leitor e agrada-me que ele fique agradado. Vou dizer a verdade: não estou contente (LISPECTOR, 1999d, p. 113).

Durante sete anos, Clarice Lispector, por questões financeiras, escreveu crônicas para o Jornal do Brasil, o que não a agradava, não só porque a assinatura do nome 
próprio deixava o seu texto automaticamente mais pessoal, mas principal-mente porque escrever toda semana era uma obrigação.

Ainda continuo um pouco sem jeito na minha nova função daquilo que não se pode chamar propriamente de crônica. E, além de ser neófita no assunto, também o sou em matéria de escrever para ganhar dinheiro. Já trabalhei na imprensa como profissional, sem assinar. Assinado, porém, fico automaticamente mais pessoal. E sinto-me como se estivesse vendendo minha alma (LISPECTOR, 1999d, p. 29).

Em outro fragmento, podemos perceber tanto uma alusão ao modo de produção da escrita clariceana quanto a situações do passado de Clarice:

\begin{abstract}
AUTOR. - Escusado dizer que Ângela nunca vai escrever o romance cujo começo todos os dias ela adia. Não sabe que não tem capacidade de lidar com a feitura de um livro. Ela é inconseqüente. Só consegue anotar frases soltas. Só há um ponto em que ela, se fosse mesmo uma realizadora de vocação, teria continuidade: é o seu interesse em descobrir a aura volátil das coisas.
\end{abstract}

ÂNGELA. - Amanhã começo o meu romance das coisas.

AUTOR. - Não começará nada. Primeiro porque Ângela nunca acaba o que começou. (LISPECTOR, 1999s, p. 102)

E cada coisa que me ocorra eu anoto para fixá-la (LISPECTOR, 1998a, p.19)

A escrita clariceana, como se presume na narração do autor, é uma escrita solta, fragmentária, como a do autor e de Ângela Pralini.

O que está escrito aqui, meu ou de Ângela, são restos de uma demolição de alma, são cortes laterais de uma realidade que se me foge continuamente. Esses fragmentos de livro querem dizer que eu trabalho em ruínas (LISPECTOR, 1999s, p. 20). 
É essa relação do passado com o presente que marca os diálogos entre o autor e Ângela Pralini e que, por meio das estratégias linguístico-semânticas, operacionaliza o jogo alusivo capaz de revelar o processo de representação autobiográfica na obra literária.

\section{Autobiografia na literatura e a representação autobiográfica}

Vários autores promovem em sua escrita encontros, talvez marcados, entre os fatos e as ficções, criando no leitor certa dificuldade em estabelecer limites entre um e outro. Entre eles, podemos citar Dostoiévisk, George Perec, Richard Wright, Marcel Proust, Jorge de Sena, Bartolomeu Campos Queirós e Graciliano Ramos. Os romances autobiográficos situam-se numa espécie de "zona de indefinição" entre o real e o ficcional, a memória e a invenção, o autor-empírico e o narrador. Assim sendo, propõese um novo jogo, que se volta agora para uma dissolução da "própria idéia de autobiografia, diluir seus umbrais, apostar no equívoco" (ARFUCH, 2010, p. 127). Para a autora, isso provoca uma confusão a respeito da identidade da voz narrativa e da referencialidade dos fatos narrados. Tal confusão ocorre quando um autor dá o seu nome à personagem ou quando faz uso da segunda ou terceira pessoa para se narrar, e da mesma forma quando ele conta uma história sabidamente ficcional, mas nela são inseridos dados verdadeiros e vice-versa.

A tendência diante de textos literários com tons autobiográficos é justamente buscar identificar essa voz enunciativa do "eu" para tentar encontrar o "verdadeiro 'eu'”' do texto, numa busca incessante pelo autor empírico, como uma forma de conhecer, de apreender a essência desse autor, como se isso fosse possível. Uma das diferenças básicas, portanto, entre a autobiografia e o romance autobiográfico é justamente a não coincidência entre autor-narrador-personagem, como propôs Philippe Lejeune (2008). A indefinição do sujeito enunciativo no romance autobiográfico leva o leitor a suspeitar de uma possível semelhança entre o narrador e 
o autor empírico. “Essa ambigüidade que caracteriza as relações entre autobiografia e romance continua a ser ponto de discussão, obrigando o leitor a um exercício constante de desautomatização" (AMORIM, 2010, p. 46). Por conta dessas ambiguidades é que, geralmente, quem lê romances do tipo desconfia da verdadeira identidade do narrador ou das personagens.

Uma solução prática que ajuda a entender a relação entre ficção e realidade é definida pelo teórico russo Mikhail Bakthin (2010) ao explorar uma argumentação que, definitivamente, muda o rumo dos estudos do gênero da autobiografia. A não demarcação entre a realidade e a ficção motivou uma série de trabalhos na tentativa de explicar a biografia pela obra e vice-versa. Segundo Bakhtin (2010), esses trabalhos ignoram, completamente, tanto o todo da personagem quanto o todo do autor. $\mathrm{O}$ pensador russo afirma que todos os elementos de uma obra são sempre uma resposta dada pelo autor não apenas ao objeto, mas também à resposta da personagem, "uma resposta à resposta". É a partir disso que

O autor acentua cada particularidade da sua personagem, cada traço seu, cada acontecimento e cada ato de sua vida, os seus pensamentos e sentimentos, da mesma forma como na vida nós respondemos axiologicamente cada manifestação daqueles que nos rodeiam (BAKHTIN, 2010, p. 3).

Para Bakhtin, é justamente nessa "resposta à resposta" que reside o caráter criativo, mas que não é imediatamente produtivo. Dessa forma, a personagem "exibirá muitos trejeitos, máscaras aleatórias, gestos falsos e atos inesperados em função das respostas volitivo-emocionais e dos caprichos de alma do autor" (BAKHTIN, 2010, p. 4). Uma personagem é autobiográfica quando alguns de seus traços coincidem com os apresentados pelo escritor na vida, o que é o caso de Ângela e do autor-narrador de Um sopro de vida, de Clarice Lispector. A tendência nesses casos é de acreditar que o autor-pessoa, na terminologia bakhtiniana, se confidencia na literatura, estando ele, 
enquanto si mesmo, na obra literária, com todos os elementos do plano ético e cognitivo ali presentes.

É preciso, contudo, ter bastante cautela ao afirmar categoricamente que o escritor, autor-pessoa, se confidencia ou se expressa na obra literária através de seu autor-criador ou de suas personagens. Dizer, aliás, que existe uma coincidência entre o autor e a personagem é um contradictio in adjecto, isso porque "o autor é elemento do todo artístico e como tal não pode coincidir dentro desse todo com a personagem, outro elemento seu" (BAKHTIN, 2010, p. 139). O material produzido com base nas declarações do escritor pode ter "um imenso valor biográfico e pode adquirir também valor estético, mas só depois de iluminado [il.] pelo sentido artístico da obra" (BAKHTIN, 2010, p. 6). Portanto, a partir do momento em que a vida passa pelo texto, podemos dizer que este remodela aquela, dando-lhe um novo significado.

A obra, contudo, não deixa de ser emblemática na constituição de um processo de referencialização do real. Como afirma Bakhtin, o autor-criador é importante para que nós, leitores, possamos compreender também o autor-pessoa. Todavia é relevante considerar que as declarações que um autor fornece sobre sua obra possuem apenas uma significação que serve aos fins de elucidação e complemento. Logo, "são particularmente absurdas comparações factuais da visão de mundo da personagem e do autor e as explicações de uma pela outra" (BAKHTIN, 2010, p. 8).

É preciso esclarecer ainda que Bakhtin não nega a possibilidade de comparações válidas, do ponto de vista científico, entre o autor e a personagem. O que ele critica é o estudo focado apenas nas relações factuais desse tema, sem nenhum critério ou princípio, o que resulta em uma confusão do autor-criador, "elemento da obra", com o autor-pessoa, "elemento do acontecimento ético e social da vida". Essa confusão é prejudicial porque, além de deformar a "personalidade ética, biográfica do autor", prejudica a compreensão "do conjunto da obra e da personagem" (BAKHTIN, 2010, p. 9). Nesse ponto, vale ressaltar uma noção importante para compreender a relação entre 
vida e obra: a noção de acabamento. Para Bakhtin, só é possível organizar e conhecer um certo todo a partir da extralocalização, do excedente de visão que escapa, no plano estético, às personagens e à obra. $\mathrm{O}$ acabamento é o todo da obra, que abrange desde as personagens em si até os elementos, os acontecimentos de suas vidas, mas nunca será um todo universal, porque o que se tem é a constituição num dado tempo e espaço de um certo todo.

Como, para Bakhtin, o autor é o responsável pelo acabamento, no inacabamento do todo da personagem e do todo da obra, ele torna-se a "consciência da consciência". Ele é capaz de ter uma visão panorâmica, onipresente e onisciente, pois domina não apenas o que as personagens conhecem, como também o que está além do que é acessível a elas.

A noção de acabamento em Bakhtin comporta, além da relação do autor com a personagem, a relação do autor com o si mesmo e com o outro. Assim, numa escrita autobiográfica, o autor-criador e o autor-pessoa não poderiam se fundir completamente e de forma homogênea porque o autor-pessoa não pode realizar um acabamento de si mesmo, já que não consegue apreender todos os elementos essenciais para esse tipo de construção, ou seja, falta a ele compreender o que está atrás e além de si mesmo.

Não posso viver do meu próprio acabamento e do acabamento do acontecimento, nem agir; para viver preciso ser inacabado, aberto para mim - ao menos em todos os momentos essenciais - preciso ainda me antepor axiologicamente a mim mesmo, não coincidir com a minha existência presente (BAKHTIN, 2010, p. 11).

Além disso, a ausência de uma imagem externa não permite que o autor enxergue as expressividades volitivo-emocionais constituintes do todo. A autocontemplação que o autor faz de si mesmo esbarra na linguagem de suas autossensações internas (GEGE, 2009, p. 8 e 9). Isso significa dizer que toda tentativa 
de acabamento por parte do autor-pessoa esbarra em sua subjetividade. Portanto, o acabamento só pode ser estabelecido pelo outro, e nunca pelo si mesmo. No plano ético e social, esse acabamento, contudo, nunca se fecha, pois são sempre construções provisórias que vão se refazendo à medida que se encontram com outra alteridade.

Diante de uma escrita autobiográfica, é imprescindível a separação entre a objetividade estética e a objetividade cognitiva e ética. A segunda se estende ao plano das significações reais e concretas, enquanto aquela se refere, axiologicamente, ao todo da personagem e da obra, estando os valores éticos e cognitivos a ela subordinados. Evidentemente, há, para Bakhtin, uma incorporação dos elementos ético-cognitivos na atividade estética, mas eles nunca poderão participar do acabamento.

Assim, é possível que a personagem esteja no autor, mas como ela mesma, e não como o autor-pessoa. Nessa perspectiva, para se chegar ao autor, é preciso, antes, "escolher todos os elementos que concluem a personagem e os acontecimentos de sua vida, por princípio, transgredientes à sua consciência, e definir a unidade ativa, criativamente tensa e de princípio desses elementos" (BAKHTIN, 2010, p. 12).

Alerta-nos Bakhtin, contudo, que nas relações entre autor e personagens autobiográficas, uma vez que o autor, pela própria dificuldade subjetiva inerente a essa tarefa, não consegue se situar, axiologicamente, tanto ao lado quanto do lado de dentro e de fora da personagem, a deformação torna-se inevitável, uma vez que

O autor vivencia a vida da personagem em categorias axiológicas inteiramente diversas daquelas em que vivencia sua própria vida e a vida de outras pessoas - que com ele participam do acontecimento ético aberto e singular da existência -, apreende-a em um contexto axiológico inteiramente distinto (BAKHTIN, 2010, p. 13).

Como já situamos anteriormente, é possível que os elementos ético-cognitivos se cruzem com os elementos estéticos, mas esse imbricamento não resulta em uma 
autobiografia, mas em uma representação autobiográfica, já que o autor, quando fala de si, não fala da posição do eu, mas na posição do outro, ou seja, ele é o outro de si mesmo:

O autor deve colocar-se à margem de si, vivenciar a si mesmo não no plano em que efetivamente vivenciamos a nossa vida; só sob essa condição ele pode completar a si mesmo, até atingir o todo, com valores que a partir da própria vida são transgredientes a ela e lhe dão acabamento; ele deve tornar-se outro em relação a si mesmo, olhar para si mesmo com os olhos do outro (BAKHTIN, 2010, p. 13).

Assim sendo, fica mais fácil compreender que

A coincidência pessoal 'na vida' da pessoa de quem se fala com a pessoa que fala não elimina a diferença entre esses elementos no interior do todo artístico. Pode-se perguntar como eu represento a mim mesmo diferentemente da pergunta: quem sou? (BAKHTIN, 2010, p. 139).

Quando o autor presume o todo da consciência do outro e o assimila em sua própria consciência, os elementos do plano ético e cognitivo perdem a força. Mesmo que ele consiga captar realmente esse todo, nunca vai corresponder à realidade, diante da própria impossibilidade de acabamento do autor. Logo, "quando o autor-pessoa se auto-objetiva esteticamente na personagem, não deve ocorrer esse retorno de si mesmo" (BAKHTIN, 2010, p.14-15). Até mesmo porque a autobiografia, como salienta Arfuch (2010, p. 54-55), além de capturar o leitor em uma rede peculiar de veridicidade, "permite ao enunciador a confrontação rememorativa entre o que era e o que chegou a ser, isto é, a construção imaginária de si mesmo como outro".

A própria personagem autobiográfica é uma personagem inacabada, pois não aceita a conclusão do autor. “Personagem deste tipo é infinita para o autor, isto é, tudo está sempre a renascer, reclamando novas e mais novas formas de acabamento que ela mesma destrói com sua autoconsciência" (BAKHTIN, 2010, p. 18). E se, de fato, o texto clariceano é, em grande medida, existencial, também não se pode duvidar de que os 
textos autobiográficos, como bem disse Arfuch (2010), trazem para a escrita um eu que está além de si mesmo. E "esse além de si mesmo de cada vida em particular é talvez o que ressoa, como inquietude existencial, nas narrativas autobiográficas" (ARFUCH, 2010, p. 39).

A afirmação de Bakhtin nos faz pensar e repensar as relações entre a enunciação e a história, que podem já não andar pari passu, mas destoantes em função da própria linguagem, que lhes assegura o espaço (auto)representativo:

Não se tratará então de adequação, da 'reprodução' de um passado, da captação 'fiel' de acontecimentos ou vivências, nem das transformações 'na vida' sofridas pelo personagem em questão, mesmo quando ambos - autor e personagem - compartilham o mesmo contexto. Tratar-se-á, simplesmente, de literatura: essa volta de si, esses estranhamento do autobiográfico, não difere em grande medida da posição do narrador diante de qualquer matéria artística e, sobretudo, não difere radicalmente dessa outra figura, complementar, a do biógrafo - um outro ou 'um outro eu', não há diferença substancial -, que, para contar a vida de seu herói, realiza um processo de identificação e, consequentemente, de valoração (ARFUCH, 2010, p. 55; Grifos da autora).

A representação autobiográfica de Clarice em suas obras literárias é particularmente sentida pelas relações alusivas que são estabelecidas no texto, desde o título, passando pelas epígrafes, até os diálogos entre Ângela e o autor. As epígrafes usadas pela autora no início de Um sopro de vida, por exemplo, aludem não apenas às relações internas estabelecidas no texto, mas, e talvez principalmente, ao significado de literatura para a própria Clarice, como produtora de novas realidades, como possibilidade criativa que, a partir dessa criação, pode se recriar, se representar.

Do pó da terra formou Deus-Jeovah o homem e soprou-lhe nas narinas o fôlego de vida. E o homem tornou-se um ser vivente (Gênesis 2, 7).

A alegria absurda por excelência é a criação (Nietzsche). 
O sonho é uma montanha que o pensamento há de escalar. Não há um sonho sem pensamento. Brincar é ensinar idéias (Andréa Azulay).

Haverá um ano em que haverá um mês, em que haverá uma semana em que haverá um dia em que haverá uma hora em que haverá um minuto em que haverá um segundo e dentro do segundo haverá o não tempo sagrado da morte transfigurada (Clarice Lispector).

A primeira epígrafe alude ao mito da criação, ao momento inaugural da existência, quando Deus sopra no homem o fôlego da vida e este passa a ser uma alma vivente. A citação é retirada do primeiro livro do Pentateuco, do Antigo Testamento da Bíblia. Essa alusão traz para a narrativa clariceana um caráter de iniciação sagrada. A literatura é percebida como um espaço de reivindicação de uma realidade que se quer atingir, como podemos perceber no seguinte fragmento:

Eu quero a verdade que só me é dada através do seu oposto de sua inverdade. E não agüento o cotidiano. Deve ser por isso que escrevo (LISPECTOR, 1999s, p. 18).

As citações aludem àquilo que a literatura proporciona à escritora, que é a capacidade de criar através da palavra, da alegria que disso resulta, da forma lúdica de se apropriar da palavra para ensinar algo a alguém e como forma de, ao se ficcionalizar, tornar-se imortal. O título da obra literária em estudo também traz uma alusão que dialoga com as epígrafes usadas. Clarice usa tanto no título de Um sopro de vida, que alude à criação, quanto dentro do texto, uma série de citações que vão, da mesma forma, aludir a esse caráter que a palavra tem de fundar a(s) realidade(s). A palavra "sopro", aliás, também pode ser usada para designar "palavra", de forma que o próprio título já traz em si uma alusão à literatura, à palavra dotada da capacidade de dar vida. 
Para Clarice, portanto, é por intermédio do natural que se chega ao sobrenatural. Ou seja, é a partir do sopro, da palavra, que se chega à vida, à literatura, à fantasia, à realidade. Assim sendo, podemos considerar que há, de fato, no texto clariceano elementos de sua biografia que, por meio do jogo alusivo, se tornam perceptíveis ao leitor. No entanto todos esses elementos, ao passarem para a obra literária, não podem mais ser considerados como integrantes de uma autobiografia, como narrativa que aborda os elementos próprios da vida da escritora, mas sim como formas de uma representação autobiográfica.

\section{Considerações finais}

A partir da análise do nosso corpus e levando em consideração as relações estabelecidas entre o real e o ficcional em Um sopro de vida, podemos dizer que é válido considerarmos a leitura da obra literária sob o viés da alusão, como um meio de recuperar o(s) sentido(s) do texto. A alusão, na condição de estratégia de leitura e de escrita, provoca o movimento de sentido do texto, possibilitando ao leitor assumir o papel de transformador dos sentidos.

A nossa pesquisa confirmou uma possibilidade de leitura literária mediada pelas estratégias linguístico-discursivas do jogo alusivo. Nesse sentido, destacamos a importância da memória, da metáfora e da metonímia na constituição desse jogo. Tais estratégias refletem, mas também refratam a constituição de uma escrita autobiográfica no corpus e, assim, o leitor, ao fazer as alusões, também joga o jogo simbiótico entre o real e o ficcional no texto clariceano.

Ao mesmo tempo, a memória, a metáfora e a metonímia, que constituem o jogo alusivo, indiciam uma escrita muito mais representativa do sujeito do que autobiográfica.

Dessa forma, no que tange à suposta autobiografia de Clarice Lispector em $U m$ sopro de vida, há de se dizer que essa possibilidade não deve ser levada às últimas 
consequências, uma vez que, mesmo em textos de fato pertinentes ao gênero da autobiografia, o real se perde no emaranhado de representações do sujeito enunciativo.

Logo, defendemos que o nosso corpus, de fato, apresenta impressões autobiográficas, percebidas a partir da inserção de elementos da vida e do cotidiano de Clarice no texto ficcional. No entanto entendemos que essas intervenções do mundo externo no texto proporcionam a construção de um novo sujeito, não sendo, dessa forma, possível falar de uma autobiografia na literatura, mas de uma representação autobiográfica no interior do texto ficcional.

Tendo suas bases na linguística, acreditamos que esta investigação é uma contribuição aos estudos do texto literário, não apenas no âmbito acadêmico, mas, principalmente, no âmbito escolar, os quais passam a contar com a alusão como estratégia de leitura e de escrita, que permite ao leitor constituir o(s) sentido(s) do texto, visto que tudo está num constante vir a ser.

A alusão é a estratégia acionada para mediar a relação entre o real e ficcional em Um sopro de vida, permitindo-nos fazer uma leitura voltada para a representação autobiográfica da escritora na obra, ampliando dessa forma as possibilidades de leitura do texto literário.

\section{Referências}

AMORIM, O. N. de. O desvio autobiográfico em Sinais de fogo, de Jorge de Sena. In: NIGRO, C. M. N.; BUSATO, S.; AMORIM, O. N. de (org.). Literatura e representações do eu: impressões autobiográficas. São Paulo: Ed. UNESP, 2010. DOI https://doi.org/10.7476/9788539304417.

ARFUCH, L. O espaço biográfico: dilemas da subjetividade contemporânea. Rio de Janeiro: EdUERJ, 2010. DOI https://doi.org/10.22409/geographia2009.v11i22.a13587.

AUTHIER-REVUZ, J. Nos riscos da alusão. Tradução: Ana Vaz e Doris Arruda Carneiro da Cunha. Revista Investigações. v. 20, n. 2, jul./2007. Disponível em: http://www.revistainvestigacoes.com.br/Volumes/Vol.20.N.2 2007 ARTIGOSWEB/Ja 
cquelineAuthier-Revuz NOS-RISCOS-DAALUSAO Vol20-N2 Art01.pdf. Acesso em: 18 mar. 2010.

BAKHTIN, M. Estética da criação verbal. São Paulo: Martins Fontes, 2010.

BUSATO, S. A memória do sujeito e a memória da linguagem: redes textuais. In: NIGRO, C. M. N.; BUSATO, S.; AMORIM, O. N. de (org.). Literatura e representações do eu: impressões autobiográficas. São Paulo: Ed. UNESP, 2010. DOI https://doi.org/10.7476/9788539304417.

CHEVALIER, J.; GHEERBRANT, A. Dicionário de símbolos: mitos, sonhos, costumes, gestos, formas, figuras, cores, números. Rio de Janeiro: J. Olympio, 1995.

ECO, U. Lector in fabula: a cooperação interpretativa nos textos narrativos. São Paulo: Perspectiva, 2008.

GOTLIB, N. B. Clarice: uma vida que se conta. 6. ed. São Paulo: Editora da Universidade de São Paulo, 2009. DOI https://doi.org/10.11606/issn.25952501.rusp.1986.132205.

GRUPO DE ESTUDOS DOS GÊNEROS DISCURSIVOS - GEGE. Palavras e contrapalavras: glossariando conceitos, categorias e noções de Bakhtin. São Carlos: Pedro e João Editores, 2009.

KOSIK, K. Dialética do concreto. Tradução: Célia Neves e Alderico Toríbio. $6^{\underline{a}}$ reimp. São Paulo: Paz e Terra, 1995.

LEJEUNE, P. O Pacto autobiográfico. Tradução: Jovita Maria Gerheim Noronha e Maria C. Guedes. Belo Horizonte: editora UFMG, 2008. DOI https://doi.org/10.12957/matraga.2017.30189.

LISPECTOR, C. Água viva. Rio de Janeiro: Rocco, 1998a.

LISPECTOR, C. A descoberta do mundo. Rio de Janeiro: Rocco, 1999d.

LISPECTOR, C. Um sopro de vida. Rio de Janeiro: Rocco, 1999s.

LISPECTOR, C. Entrevistas. Rio de Janeiro: Rocco, 2007.

MOSER, B. Clarice. São Paulo: Cosac Naify, 2009. 
QUEIRÓS, B. C. Ler, escrever e fazer conta de cabeça. 2. ed. Belo Horizonte: Muguilin, 1996.

TORGA, V. L. M. “Aludir é melhor que nomear": a leitura e a alusão no texto literário. In: A Cor das Letras: Revista do Departamento de Letras e Artes da Universidade Estadual de Feira de Santana. - n. 1 (1997). - Feira de Santana: UEFS, 1997. DOI https://doi.org/10.13102/cl.v8i1.1576.

TORGA, V. L. M. O movimento de sentido da alusão: uma estratégia textual da leitura de ler e escrever e fazer conta de cabeça de Bartolomeu Campos Queiroz. 2001. Dissertação (Mestrado em Linguística Aplicada) - Faculdade de Letras, Universidade Federal de Minas Gerais, Belo Horizonte, 2001. DOI https://doi.org/10.26512/aguaviva.v2i1.10324.

TORGA, V. L. M. O Risco do Bordado de Autran Dourado: A alusão nos gêneros textuais: o romance e a tese. 2006. Tese (Doutorado em Letras: Linguistica) - Faculdade de Letras, Universidade Federal de Minas Gerais, Belo Horizonte, 2006. DOI https://doi.org/10.5752/3157.

TORGA, V. L. M. Crônicas de Machado de Assis: pra quem sabe lê, um "pinguélê". Encontro Regional da ABRALIC 2007, realizado entre os dias 23 a 25 de julho de 2007, na USP, São Paulo-Brasil. DOI https://doi.org/10.5962/bhl.title.110909. Disponível em: www.abralic.org.br/enc2007/anais/16/638.pdf. Acesso em: 22 nov. 2008. 